\title{
Where's populism? Online media and the diffusion of populist discourses and styles in Portugal
}

\author{
Susana Salgado ${ }^{1}$
}

Published online: 22 January 2018

(C) The Author(s) 2018

\begin{abstract}
Portuguese politics and mainstream media have been resistant to the recent spread of populism. This article examines the specific features of Portuguese politics and media that might explain the apparent exception, and puts it to test by analysing the prevalence of populist discourses and styles of communication in different types of online media. The sample is composed of mediated and unmediated messages on immigration and corruption, two issues that are commonly present in populist discourses by both right- and left-wing political actors. Overall, the content analysis shows that although populist discourses are not recurrent in politics and media, social media have amplified the visibility of this kind of discourses in Portugal.
\end{abstract}

Keywords Media · Online · Politics · Populism · Portugal · Corruption · Immigration $\cdot$ Political communication $\cdot$ Political discourse

\section{Introduction}

Specific features of Portugal's recent past and of its party system have rendered the success of populist political actors particularly difficult. On the one hand, a diffuse, enduring rejection of extreme right-wing ideas, parties, and movements is explained by the burden of the past Salazar dictatorship. On the other hand, left-wing parties as the Left Bloc (BE) and the Communist Party (PCP) have been functioning as important aggregators of popular discontent without having become empty ideological shells or populist parties. Particularly, PCP and the trade unions linked to it have an important role in channelling discontent into popular demonstrations,

Susana Salgado

susanapsalgado@gmail.com

1 Universidade de Lisboa, Instituto de Ciências Sociais, Av. Prof. Aníbal Bettencourt 9,

1600-189 Lisbon, Portugal 
thus efficiently "occupying the streets" and most protest spaces, which seems to be preventing the development of other types of strong independent grassroots movements, not directly linked to existing political parties.

Does this mean that we cannot find populist political discourses and communication in Portugal? Is the weight of contextual factors too overpowering to allow the emergence of populism in political discussions on issues? By looking at the specific characteristics of Portugal's political and media systems, this article advances the contextual factors that limit the success of populist political actors in Portugal. Given that mainstream media have also been resistant to populist actors, this research then examines the prevalence of elements of populist discourse in different online environments, including in the online presence of mainstream media.

Preliminary research suggests that different political actors have been using online and social media as vehicles of less-institutionalized, direct communication (e.g. Groshek and Engelbert 2013; Nixon et al. 2015) and that the discussion of divisive issues tends to polarize positions and entail features of populist discourse (Salgado 2015). Following Jagers and Walgrave (2007) conceptualization of populism as a political communication style, this study relies methodologically on content analysis to look at the discourse of different types of actors and examine news and discussions on issues that are often related to populism, such as immigration and corruption. The overall objective is to determine how immune Portuguese politics and society are to the recent surge of populism in Europe.

\section{Portuguese politics at the fringes of populism}

The recent surges of populism in southern Europe have emerged mainly as a response to economic and political decline (see also Salgado and Stavrakakis 2018). The adverse economic and financial situation with the Euro Crisis and the growingly strained relationships between some EU member countries, caused by imbalances in decision-making at the European level, have exposed the imperfect nature of the European integration processes and some of Eurozone's structural problems (Picard 2015; Salgado and Nienstedt 2016). While in some cases the political and economic weaknesses have been a key element in populist arguments against the "establishment" (national and EU political and economic elites), in other cases they have furthered discourses against immigration and globalization. These are emotionally appealing narratives that distort information about facts and issues and tend to bipolarize discussions and positions; important contextual information is also usually disregarded in order to serve specific purposes (polarize society, magnify and inflame discontents, engender protest and mobilization, etc.).

The emergence of populist discourses and actors in Europe can also be framed within the crisis of the European model of social democracy, especially in countries with increasingly aged populations (according to the 2015 United Nations report, Portugal is one of the ten most ageing countries in the world), because of the longterm unsustainability of generous welfare benefits. Scarcity of resources inevitably limits those who are covered by benefits, which in turn weakens social cohesion and 
causes popular unrest and conflict, and populist discourses are often successful in combining and magnifying discontent and reactions against the status quo (for an empirical analysis of the link between welfare benefits and support for radical rightwing populism, see Swank and Betz 2003, and for a more recent approach, see also Inglehart and Norris 2016).

Facing the 2011 bailout, the weight of austerity, and a climate of political crisis, the Portuguese political system was, however, able to adjust itself through inner changes, countering the emergence of successful anti-system populist parties. A good example was the political parties' reaction to the 2015 election results and the parliamentary left coalition built to support a Socialist Party (PS) government and prevent the incumbent conservative coalition [PSD (Social Democratic Party)/CDS$\mathrm{PP}]$ from taking office. The PSD/CDS-PP coalition won the election, but without absolute majority, which, given the parliament's new configuration after the election (the remaining political parties were all centre left or left wing oriented), made it impossible for the coalition to forge a parliamentary majority to support its government. This was the first time that PCP (Communist Party), PEV (Green Party), and BE (Left Bloc) jointly supported the socialists in a durable agreement which allowed the formation of a socialist (PS) government with the objective of preventing a second PSD/CDS-PP coalition government (the former ruled from 2011 to 2015).

Both right and left populist political parties and leaders have not been as successful in Portugal as in other countries in Europe, including in Southern Europe. The election results of the National Renovator Party (PNR, a political party that is inspired by the French Front National) have been negligible since its emergence in 2000 ( $0.5 \%$ in the 2015 election), and occasionally, political leaders with a more populist style of communication emerge, but usually they are unsuccessful in convincing voters or end up adjusting their discourse to the established system after being elected. This was the case of Paulo Portas, the Democratic and Social CentrePeople's Party (CDS-PP) former leader, who in the 1990s was anti-immigration, and sceptical of the European Union, but changed substantially the discourse after joining a coalition government in 2002. A more recent case is Marinho e Pinto. Before being elected to the European Parliament in 2014, Marinho e Pinto's political discourse was full of populist features: it was against the "establishment" and included anti-elite and "us" versus "them" arguments. However, in the 2015 general election his new party PDR (Democratic Republican Party) was only able to secure $1,14 \%$ of the votes. Also without major repercussions were the social movements Geração à Rasca (Struggling Generation) and the 12th March Movement (M12M) that emerged in the beginning of 2011, but did not evolve into alternative political parties, as it happened in Greece and Spain (Salgado and Zúquete 2017; for an analysis of social mobilization in Portugal in this period, see, for example, Estanque et al. 2013).

Portugal's recent history and more specifically the inheritance of a long period of dictatorship (1933-1974) also contributes to explain the absence of successful extremist parties. Not only this kind of political organizations is stigmatized, but the Constitution also establishes as a limit to freedom of association all kinds of fascist (and racist) organizations (article 46). The influence of the recent past is furthermore 
extended to the failure of anti-system discourses: culturally, voters have been (at least, so far) less prone to support unestablished parties and unknown political leaders, because of the uncertain consequences of such political choices. Nonetheless, the growing criticisms of the EU's decision-making processes and of the overall opaqueness of EU bureaucracy may urge some voters to support the strands of populism that call for a regeneration of democracy and a better representation of the citizens' interests, as it happened in Spain with Podemos, for example (see Iglesias 2015; for a general overview of challenger parties in Europe, see Hobolt and Tilley 2016).

Despite the presence of the very same elements found in countries where populist actors have been receiving more support (for further detail on Greece, Spain, and Italy, see in this symposium Stavrakakis and Katsambekis 2018; Kioupkiolis and Seoane Pérez 2018; Bobba 2018, respectively), different kinds of constraints have, thus, made it particularly difficult for populist actors to thrive in Portugal. Portugal was one of the countries that most felt the Euro Crisis, and it has also experienced a crisis in the legitimacy of political elites and a climate of distrust against politicians in general, and, although less pronounced, the weakening of centrist political parties that has been happening in other countries (e.g. Spain, Greece, France) also happened in Portugal. But nevertheless, it was not a fertile ground for populism.

\section{Portuguese media and populism}

The negative connotation that populism has in Portuguese politics is also found in the media (Salgado and Zúquete 2017). Not only it is common to see politicians labelling opponents or their proposals as populist (in the sense of having electioneering goals or being over-simplistic) to delegitimize them, but it is also usual to find the words "populist" or "populism" when commentators and journalists intend to criticize someone or something (e.g. a style of political communication, a political proposal, or a policy orientation). Furthermore, in opinion pieces, populism is often "equated with simple-mindedness, lack of sophistication, and an overly emotional and moralistic approach to politics" (Salgado and Zúquete 2017: 242).

Although there is no systematic longitudinal research to empirically support inferences of prevalence or absence of populism in Portuguese media outlets, regarding both the coverage of the few populist actors and the use of populist frames in news coverage in general, some evidence suggests the negligibility of such features in the most important news media outlets. "For the most part, Portuguese media, particularly quality newspapers and mainstream television channels, are hostile toward manifestations of political populism and try to critically deconstruct it" (Salgado and Zúquete 2017: 242). For example, extreme right-wing actors have, on different occasions, expressed difficulties in getting their events and messages covered by mainstream media. And Marchi noted that PNR's scarce media coverage has usually a negative tone; PNR is depicted as "an extremist group nostalgic for the former authoritarian regime" (2013: 150). 
Despite the resistance of Portuguese media to populism, it should be noted that media populism in the sense that Mazzoleni described, which points to a link between media populism and popular culture and to a media's market-driven alignment-even if acknowledging "different degrees of responsiveness to popular tastes and demands" (2003: 8) —is as present in Portugal as in other European countries through tabloid newspapers, talk radio, infotainment television, etc.; however, this definition has a connotation of populism that is directly linked to the notion of popular culture, as well as to the inner character of mass media (Mazzoleni 2014), in the sense of pleasing audiences (e.g. formats such as soft news or docudrama series, for instance). Furthermore, although strategies may have varied through time, media outlets have always tried to capture the public's attention, and in line with this approach, they tend to personalize coverage, dramatize events, and simplify complex issues, just as populist actors, who also use simple language and tend to emotionalize and dramatize discourses (see, for example, Beppe Grillo in Italy, or Marinho e Pinto in Portugal).

Krämer proposes a different conceptualization of media populism, in the sense that to be considered populist, media outlets need to display specific ideological and stylistic elements, such as "construction and favouritism of in-groups, hostility toward, and circumvention of the elites and institutions of representative democracy, reliance on charisma and common sense, and appeal to moral sentiments" (2014: 48). This means that, depending on their characteristics, media outlets may or may not be fertile ground to populist actors and discourses.

The stance adopted by the media towards populist actors is particularly important given that the success of any political actor is at least in part media driven (Altheide and Snow 1979; Mazzoleni 2003; Stanyer et al. 2017). But these phenomena are not straightforward: in some cases, the lack of media exposure or a negative media bias may contribute to political failure, but in other cases, it may be precisely the exclusion from mainstream media or a negative coverage that forces the use of alternative media (e.g. social media) that has advantages, namely allowing to establish direct communication channels with citizens, while bypassing mainstream media formats, which helps in building an image of "alternative", more appealing at the eyes of some dissatisfied voters; prime examples of this strategy include the use of Twitter by Donald Trump (see, for example, Ott 2017) and the use of social media by Beppe Grillo (see, for example, Mosca 2014).

In Portugal, mainstream politicians and journalists maintain close ties, and since there is not much investigative journalism, journalists overly rely on politicians as sources of information (Mesquita 2003). Overall, the media agenda is determined by a mix of what journalists believe is the audience demand and news values, but also by the political agenda and partisan political pressures (Salgado 2007, 2018). The government, the president, and the parties with the most votes have a stronger negotiating power with the media and usually have more media coverage (Salgado 2007), which means that they are strong influences on how issues and political developments are framed and interpreted. It is common to see journalists accepting invitations to work in politics, and many mainstream politicians as regular commentators in media outlets. It was, for example, the case of President Marcelo Rebelo de Sousa, who became well known to the public due to his regular 
commentaries in prime-time media since the 1990s (Salgado 2018). As a result, mainstream journalists are often perceived as belonging to the elite and to the establishment.

Despite of these close links, news outlets do not express directly their party preferences (a noteworthy exception was the support of newspaper Correio da Manha to a candidate in a municipal election) and their ownership is independent from political parties. Specific media legislation was prepared in the aftermath of the 1974 revolution to ensure media independence, but it is also part of a commercial strategy by news outlets to not drive readers/viewers away. However, it is not uncommon to detect partisan bias in news content through the salience attributed to certain issues, events and actors; the commentators selected to contextualize and interpret the news, and in some opinion articles. All this potentially affects the public's political perceptions and knowledge.

\section{Features of populist style and discourses: the methodological approach}

The present study of the presence of populist features in online environments is not restricted to extreme right-wing parties, because left-wing and mainstream parties, as well as other kinds of actors, may also display populist elements in their communication; it therefore includes the political parties with parliamentary representation (Social Democratic Party-PSD; Socialist Party-PS; Democratic and Social Centre-People's Party-CDS-PP; Left Bloc-BE; Communist PartyPCP; Green Party-PEV), plus the populist PNR (National Renovator Party) and PDR (Democratic Republican Party). Furthermore, some issues, such as immigration, corruption, and other contentious issues, are particularly prone to populist political communication by different political actors. Immigration is one of the most important issues on the agenda of extreme right populist political actors (see, for example, Walgrave and de Swert 2004; Bos and van der Brug 2010), whereas corruption lays at the foundation of any basic populist argument, the "pure people" against the "corrupt elite" (e.g. Mudde 2004), and is often used by both right- and left-wing populist political actors.

In addition to their relevance to populist discourses, the issues of immigration and corruption have also a considerable agenda salience. Due to the refugee crisis and the discussion behind Brexit, there has been an ongoing debate on immigration. Corruption has also been very present in the agenda, because of the arrest and criminal investigation of former prime minister José Sócrates; the recent scandals involving some secretaries of state, which relaunched the debate on the close relationship between the political elite and corporate interests in Portugal; the "Lava-Jato" scandal in Brazil involving former president Lula da Silva and the removal of president Dilma Roussef; the situation of widespread corruption in Angola and the Angolan political elite alleged strategy of money laundering by buying assets in Portugal; the corruption scandals within the Spanish People's Party (PP); or the Panama papers investigation, just to give a few examples.

Following Jagers and Walgrave (2007) proposal that defines populism primarily as a political communication style and because we can find populism in different 
ideologies and in different types of political parties (right, centre, left, mainstream, fringe) as well as in other actors, this analysis is focused on political information and communication and not on political ideology. Specifically, it studies online news and comments from newspapers' websites, and Facebook posts by political parties on issues associated with populism, immigration and corruption, through content analysis.

Regardless of political leaning and ideology, populist discourses and styles entail distinctive elements. A common consensus view on populism is the idea that it equates "the people" with "good" and "the elites" with "evil", in the sense of a Manichean worldview (Mudde 2004). Naturally, the nature and composition of the people and the elite varies according to ideology: in right-wing populism, the notion of "the people" is directly related to a nationalist view and refers to native-born citizens, and it thus excludes foreigners and immigrants from the people; in leftwing populism, "the people" is broader, encompassing all those who are not part of the elite. But, whereas the interpretations of the people differ, these views entail a notion of the people as a constructed entity: a homogenous group without legitimate divisions and notable differences in interests. However, a distinction between elite and people is hardly populism-related only. According to Jagers and Walgrave, for political communication to be considered populist, it "always refers to the people and justifies its actions by appealing to and identifying with the people; is rooted in anti-elite feelings; and considers the people as a monolithic group without internal differences except for some specific categories" that are excluded (2007: 322).

Populism is also related to other important elements: it often entails direct political communication strategies, through both the choice of means of communication and the use of specific stylistic options in the political discourse. But it is important to stress, as Mudde and Kaltwasser (2012) do, that it is not clear which features of populism are constitutive elements or empirical consequences of populism.

Given that the present study is based on an exploratory approach aimed at detecting traces of populism in different online environments, it includes three different types of units of analysis, namely news items on immigration and corruption that were published in three daily newspapers with online presence: two reference newspapers, a centre-left (Público) and a centre-right (Observador), and a tabloid paper (Correio da Manhâ). Extant literature (Mazzoleni 2003) suggests that when compared with reference newspapers, tabloid papers display higher degrees of populism in their news coverage, due to a more popular approach not only in language and visuals, but also in the selection and presentation of news (e.g. crimes, use of emotions and drama).

The analysis also includes two types of unmediated online content: the readers' comments to the selected news stories and posts published by political parties on their Facebook pages. Two main reasons justify the inclusion of the readers' online comments: first, although they may not be fully representative of public opinion, they are written by common citizens and are therefore expressions of "the people" which are populist by nature; second, it is relevant to juxtapose the citizens' views on these issues with news items and parties' messages. Moreover, comments to news were included instead of parties' Facebook comments because they are expected to cover a broader variety of political preferences. 
Finally, the political parties' posts on Facebook that focused on immigration and corruption were also included. Because "populism is not necessarily the prerogative of populist parties" (Rooduijn et al. 2014; Stanyer et al. 2017), several political parties were analysed: the parties with parliamentary representation (PS, PSD, CDSPP, BE, PCP, and PEV), and the extreme right PNR. PDR, a recent party whose leader (Marinho e Pinto) has been considered populist, could not be included because it did not have an updated Facebook page.

This assorted sample allows comparing user-generated content published by politicians with news content filtered by gatekeepers and the online readers' comments, which are published freely but under some constraints imposed by news media outlets. Today, reading a news story online also means paying attention to the readers' comments, which can potentially influence opinions. This is all the more important if, as Groshek and Engelbert, we consider "political populism and online media uses as two interdependent trends that are central features in rapidly evolving socio-political landscapes" (2013: 184).

The coding units are thus the individual news items, online readers' comments, and parties' posts. The operationalization of populism in the content analysis follows Jagers and Walgrave (2007) conceptualization, which refers to three elements: references to the people in the sense of expressions of closeness to the people, belonging to the people, speaking on behalf of the people (forms of people centrism); anti-elitism (elites, establishment, system, mainstream politics and parties); exclusion of out-groups (immigrants and other minorities). These three elements were coded using a dichotomous scale referring to their absence or presence (no-0; yes-1) in the coding units.

Examples such as the following were included as references to the people and people centrism: "We are part of the people, our party is not a party of 'caudilhos' (the term refers to authoritarian political-military leaders) as the others"; "the people can dismiss everyone who does not agree and does not protect the interests of the people". Sentences such as "the ones who betray the people versus the serious people", "we the people against the powerful", or "we are not of the same ilk as them" were coded as containing elements of anti-elitism. Finally, statements expressing antagonism towards out-groups were also coded as indicating the presence of characteristics of populist discourse. The out-groups that were considered included immigrants in general; specific nationalities of immigrants, as Brazilians, Cape Verdeans, East Europeans, etc.; religious groups, as the Muslims; racial and ethnic groups, as the Roma community or black people; or specific political groups, which commonly referred to the political parties that have ruled the country since the 1974 democratic revolution. Blame shifting, scapegoating, and the use of simplistic dichotomies, as "good and bad", are other features of populist discourses and strategies used to oversimplify issues, but these were not systematically coded on this occasion.

In addition to identifying which-if any-features of populism are used, in which media, and by whom, that is, which actors are more prone to populist approaches to issues, this sample also allows testing whether mainstream media stigmatize populist actors and messages. The mainstream media resistance to-at least some forms of-populism (Marchi 2013; Salgado and Zúquete 2017) increases 
the interest in the analysis of social media, because they ensure direct communication channels with citizens that bypass the mainstream media gatekeepers. The approach thus examines whether online unmediated media environments are somehow contributing to convey and legitimize populist discourses and styles.

\section{The prevalence of populist features of discourse in online media}

The data were collected from 1 May to 31 July 2016 for news items and readers' comments and from 1 February to 31 July 2016 for parties' Facebook posts. The difference in the dates is explained by the scarcity of Facebook posts; most political parties in Portugal do not update their Facebook pages frequently, and the issues of corruption and immigration were not addressed frequently by most of them (PSD, CDS-PP, and PCP do not have any posts on these issues in the selected period). All in all, small parties (BE, PNR, and to a lesser extent PEV) use Facebook much more, but except for PNR, immigration and corruption are not preferred topics. To overcome the overall shortage of political parties' messages, the direct quotes of party members in news items were also coded.

The final sample consists of 336 news items on immigration and 583 on corruption (news items with the words "immigration" and "corruption", but not actually dealing with the issues were excluded), of which $15 \%$ contained quotes from political parties; 402 readers' comments (many news items did not have any readers' comments available, especially in Correio da Manhã); and 110 Facebook posts. Two researchers coded the three types of coding units (news items, comments to news, and Facebook posts) and the intercoder reliability test that was performed included approximately $10 \%$ of each of the coding units' samples and produced satisfactory results (Krippendorff's alpha $>.71$ ).

A first noteworthy conclusion is that corruption was more salient than immigration. Not that immigration is not on the agenda, but it motivated fewer messages from politicians (except from PNR) and from citizens, as well as less news coverage. It is, however, the immigration issue that is most linked to populism in the news and comments, which might be explained by international news coverage and by the visibility of issues such as the rise of right-wing, anti-immigration parties in several European countries, the refugee crisis, or Trump's discourse against immigration.

The content analysis findings show that populism is not prevalent in Portuguese media and politics. The tabloid Correio da Manhã has a simpler language style (as well as wider headlines and more visuals), and the prevalence of elements of populism in its news items was slightly higher (8\%) when compared to Observador (6\%) and much higher than Público $(2.9 \%)$. It is important to note that, in newspapers, populist discourse was more common in opinion articles.

The most recurrent features of populism in the news coverage were references to the people (e.g. the expression "Zé Povinho", which means precisely "the people" in Portuguese) and criticism of the elites, being the discourse anti-elites particularly featured in news items on corruption (e.g. "It is not about left or right, it is the tragic nature of politics", Eduardo Dâmaso, in CM, June 29; "The fall of the Europe of the elites", Teixeira Fernandes, in Público, June 24). Most opinion articles with 
populist features were focused on the issue of corruption, and it was mainly the antielitism feature of populism that prevailed, which can be explained by the amount of corruption scandals involving the political elites and the richest both nationally and internationally and by the fact that both mainstream politicians and journalists display favourable views towards immigration.

Regarding the quotes from politicians in the news coverage, it is important to note that populism was not common and that PNR is practically absent from mainstream media coverage. Overall, accusations and blame shifting, and the use of the word "people" are present in all parties' discourses, but these in itself are not sufficient to consider their discourses as populist, because their statements did not: (1) denote an anti-establishment view; (2) deny the legitimacy of political opponents; and (3) or contest the existence and legitimacy of different groups and interests within "the people". Furthermore, a populist-style separation between the "us" and "them" was also not significant in the discourse of most political parties. This distinction is, however, pronounced in the readers' online comments, especially in corruptionrelated comments; these citizens do not feel their interests are being properly represented and many see politicians as self-serving, deceptive, and corrupt.

Right-wing populist discourses focusing on anti-immigration and exclusion of outgroups are practically absent in politics, except for the extreme right PNR's Facebook page. But they are present in readers' comments. These are spaces for citizens to intervene in public debates and where they interact with journalists and with each other, which therefore allow getting information about some of the citizens' reactions to news and issues. For example, the capacity of the frail Portuguese economy to support the coming of more immigrants and refugees is often questioned in comments, which also include expressions of fear and distrust against Muslims, related to the terrorist attacks and sexual assaults of women in Europe, especially in the readers of Observador ( $C M$ website did not have almost any readers' comments available). Some of these opinions were for instance: "It is naive to think that refugees change their beliefs when they come to Europe. They are bringing the behaviors and ideas that have made their countries a living hell"; "If Merkel wants refugees, she can keep them all in Germany". It is not possible to measure the representativeness of such comments, but it is interesting to note that the political and media elites have not voiced or addressed these citizens' angst and concerns.

The PNR Facebook page is flooded by this type of comments, as well as by other features of populism: "This mass immigration is an invasion. It is a menace to Portuguese identity, sovereignty, safety and future survival. We cannot accept any financial support to immigrants, when so many of us have so little. This immigration policy leads to the deterioration of salaries, rising crime and the dilution of our national identity"; "European workers are fed up, they are victims of the politicians' mistakes and the immigration lobby that wants cheap labour only to increase profit". The issue of corruption is also extremely important; it is used by PNR as a justification to claim for a major political reform. But PNR is the exception; the remaining political parties' online messages had very few references to any of the main elements of populism, and the most recurrent was the simple reference to the people, being "the people" mostly equated to the "country's population", "working class", and "common citizens". 


\section{Conclusion}

Different factors may trigger populism. Populism may be part of a country's political culture (Urbinati 2013); an integral component of representative politics (Taggart 2004), or a reflection of its limitations (Canovan 1999). But it can be caused by economic crises and unfair economic redistribution (e.g. Laycock 2005; Kriesi 2014), a perceived rise of corruption and moral decay (Fieschi and Heywood 2004; Taggart 2004), or political crises (Taggart 2004; Kriesi 2014), which often lead to distrust in the democratic representative system.

Portugal has experienced most of these situations, but has been resilient to populism. With the exception of the election of Marinho e Pinto for the European Parliament, the electoral success of populists in Portugal has been rather negligible and mainstream media usually counter populism. There is, however, very limited information about the presence of populist discourses and styles of communication in public debates. This exploratory approach intended to capture the prevalence of populist features in discussions about issues, by examining different types of media, and mediated and unmediated messages focused on immigration and corruption. Overall, the content analysis showed that in Portugal populist discourses and styles were more common in citizens' comments and particularly in the extreme rightwing PNR's Facebook page, but overall they were not recurrent.

The connections between mainstream media and mainstream politics are very close, and mainstream media are deemed to be part of the "establishment" in Portugal. This also explains why their permeability to populism has been quite limited. The newness of some discourses might attract coverage for some time, but mainstream media tend to disregard or be very critical of arguments that focus on structural reforms of the political system (see also Mendes 2005) and especially of right-wing extremist parties. In the case of this sample, if it were not for social media (Facebook) and the spaces for readers' comments, the visibility of populism would be almost inexistent. Alternative online media have thus allowed the introduction and dissemination of populist views on issues and of populist styles of communication in the public debate. They can, therefore, pose a challenge for mainstream media, not only in terms of formats, but also of content, while mainstream political parties may need to readjust their agendas and discourses. Somehow, this research also provides evidence that changes in the media are closely linked to political and social changes.

Funding Susana Salgado's research work is currently sponsored by the Portuguese Foundation for Science and Technology (IF/01451/2014/CP1239/CT0004).

Open Access This article is distributed under the terms of the Creative Commons Attribution 4.0 International License (http://creativecommons.org/licenses/by/4.0/), which permits unrestricted use, distribution, and reproduction in any medium, provided you give appropriate credit to the original author(s) and the source, provide a link to the Creative Commons license, and indicate if changes were made. 


\section{References}

Altheide, D., and R. Snow. 1979. Media Logic. Beverly Hills, CA: Sage.

Bobba, G. 2018. Social Media Populism: Features and likeability of Lega Nord communication on Facebook. In Populist Discourses and Political Communication in Southern Europe, Symposium European Political Science, eds. S. Salgado and Y. Stavrakakis. https://doi.org/10.1057/s41304017-0141-8.

Bos, L., and W. Van der Brug. 2010. Public Images of Leaders of Anti-immigration Parties: Perceptions of Legitimacy and Effectiveness. Party Politics 16(6): 777-799.

Canovan, M. 1999. Trust the People! Populism and the Two Faces of Democracy. Political Studies 47(1): $2-16$.

Estanque, E., H. Costa, and J. Soeiro. 2013. The New Global Cycle of Protest and the Portuguese Case. Journal of Social Science Education 12(1): 31-40.

Fieschi, C., and P. Heywood. 2004. Trust, Cynicism and Populist Anti-politics. Journal of Political Ideologies 9(3): 289-309.

Groshek, J., and J. Engelbert. 2013. Double Differentiation in a Cross-national Comparison of Populist Political Movements and Online Media Uses in the United States and The Netherlands. New Media and Society 15(2): 183-202.

Hobolt, S., and J. Tilley. 2016. Fleeing the Centre: The Rise of Challenger Parties in the Aftermath of the Euro Crisis. West European Politics 39(5): 971-991.

Iglesias, P. 2015. Politics in a Time of Crisis: Podemos and the Future of Democracy in Europe. London and New York: Verso.

Inglehart, R., and P. Norris. 2016. Trump, Brexit, and the Rise of Populism: Economic Have-Nots and Cultural Backlash. Harvard Kennedy School Working Paper Series. https://papers.ssrn.com/sol3/ papers.cfm?abstract_id=2818659.

Jagers, J., and S. Walgrave. 2007. Populism as Political Communication Style: An Empirical Study of Political Parties' Discourse in Belgium. European Journal of Political Research 46(3): 319-345.

Kioupkiolis, A., and F. Seoane Pérez. 2018. Reflexive Technopopulism: Podemos and the Search for a New Left-Wing Hegemony. In Populist Discourses and Political Communication in Southern Europe, Symposium European Political Science, ed. S. Salgado, and Y. Stavrakakis. https://doi.org/ 10.1057/s41304-017-0140-9.

Krämer, B. 2014. Media Populism: A Conceptual Clarification and Some Theses on its Effects. Communication Theory 24(1): 42-60.

Kriesi, H. 2014. The Populist Challenge. West European Politics 37(2): 361-378.

Laycock, D. 2005. Visions of Popular Sovereignty: Mapping the Contested Terrain of Contemporary Western Populisms. Critical Review of International Social and Political Philosophy 8(2): 125-144.

Marchi, R. 2013. The Extreme Right in 21st Century Portugal: The Partido Nacional Renovador. In Right-Wing Extremism in Europe: Country Analyses, Counter-Strategies and Labor-Market Oriented Exit Strategies, ed. R. Melzer, and S. Serafin, 133-156. Berlin: Friedrich-Ebert-Stiftung.

Mazzoleni, G. 2003. The Media and the Growth of Neo-Populism in Contemporary Democracies. In The Media and Neo-populism. A Contemporary Comparative Analysis, ed. G. Mazzoleni, J. Stewart, and B. Horsfield, 1-20. Westport: Praeger.

Mazzoleni, G. 2014. Mediatization and Political Populism. In Mediatization of Politics. Understanding the Transformation of Western Democracies, ed. F. Esser, and J. Strömbäck, 42-56. Basingstoke: Palgrave Macmillan.

Mendes, J.M. 2005. Só é vencido quem deixa de lutar: Protesto e Estado Democrático em Portugal. Revista Crítica de Ciências Sociais 72: 161-185.

Mesquita, M. 2003. O Quarto Equívoco. O poder dos media na sociedade contemporânea. Coimbra: MinervaCoimbra.

Mosca, L. 2014. The Five Star Movement: Exception or Vanguard in Europe? The International Spectator 49(1): 36-52.

Mudde, C. 2004. The Populist Zeitgeist. Government and Opposition 39(4): 541-563.

Mudde, C. and C.R. Kaltwasser (eds.). 2012. Populism in Europe and the Americas: Threat or Corrective for Democracy?. Cambridge: Cambridge University Press.

Nixon, P., D. Mercea, and R. Rawal. 2015. Introduction. In Politics and the Internet in Comparative Context: Views from the Cloud, ed. P. Nixon, R. Rawal, and D. Mercea. London and New York: Routledge. 
Ott, B. 2017. The Age of Twitter: Donald J. Trump and the Politics of Debasement. Critical Studies in Media Communication 34(1): 59-68.

Picard, R. (ed.). 2015. The Euro Crisis in the Media: Journalistic Coverage of Economic Crisis and European Institutions. London and New York: I.B.Tauris.

Rooduijn, M., S. Lange, and W. Brug. 2014. A Populist Zeitgeist? Programmatic Contagion by Populist Parties in Western Europe. Party Politics 20(4): 563-575.

Salgado, S. 2007. Os Veículos da Mensagem Politica. Estudo de uma campanha eleitoral nos media [The Vehicles of Political Communication. Studying an Electoral Campaign in the Media]. Lisboa: Livros Horizonte.

Salgado, S. 2015. Populism or Policy? A Comparative Analysis of Portuguese and Spanish Political Parties' Websites. Paper presentation at the COST Action IS1308 Workshop "New Perspectives on Populist Political Communication", University of Zurich, Switzerland, 26-30 January 2015.

Salgado, S. 2018. O factor media e as estratégias de construção de imagem dos candidatos presidenciais [The Media Factor and the Presidential Candidates' Strategies of Image Building]. In Presidentes $e$ (Semi) Presidencialismo nas Democracias Contemporâneas, ed. A. Costa Pinto, P.C. Rapaz. Lisboa: Imprensa Ciências Sociais.

Salgado, S., and H.W. Nienstedt. 2016. Euro Crisis and Plurality: Does the Political Orientation of Newspapers Determine the Selection and Spin of Information? European Journal of Communication 31(4): 462-478. https://doi.org/10.1177/0267323116659977.

Salgado, S., and J.P. Zúquete. 2017. Portugal: Discreet Populisms Amid Unfavorable Contexts and Stigmatization. In Populist Political Communication in Europe, ed. T. Aalberg, F. Esser, C. Reinemann, J. Strömbäck, and C. Vreese, 235-248. London \& New York: Routledge.

Salgado, S., and Y. Stavrakakis. 2018. Introduction: Populist Discourses and Political Communication in Southern Europe. In Populist Discourses and Political Communication in Southern Europe, Symposium European Political Science. ed. S. Salgado, and Y. Stavrakakis. https://doi.org/10.1057/ s41304-017-0139-2.

Stanyer, J., S. Salgado, and J. Strömbäck. 2017. Populist Actors as Communicators or Political Actors as Populist Communicators: A Cross-National Findings and Perspectives. In Populist Political Communication in Europe, ed. T. Aalberg, F. Esser, C. Reinemann, J. Strömbäck, and C. de Vreese, 353-364. London \& New York: Routledge.

Stavrakakis, Y., and G. Katsambekis. 2018. The Populism/Anti-populism Frontier and its Mediation in Crisis-Ridden Greece: From Discursive Divide to Emerging Cleavage? In Populist Discourses and Political Communication in Southern Europe, Symposium European Political Science. ed. S. Salgado, and Y. Stavrakakis. https://doi.org/10.1057/s41304-017-0138-3.

Swank, D., and H.-G. Betz. 2003. Globalization, The Welfare State and Right-Wing Populism in Western Europe. Socio-Economic Review 1(2): 215-245.

Taggart, P. 2004. Populism and Representative Politics in Contemporary Europe. Journal of Political Ideologies 9(3): 269-288.

United Nations, Department of Economic and Social Affairs, Population Division. 2015. World Population Ageing 2015 (ST/ESA/SER.A/390).

Urbinati, N. 2013. The Populist Phenomenon. Raisons Politiques 51(3): 137-154.

Walgrave, S., and K. de Swert. 2004. The Making of the (Issues of the) Vlaams Blok. Political Communication 21(4): 479-500.

Susana Salgado is currently FCT research fellow at the Institute of Social Sciences, University of Lisbon, where she also teaches political communication and media studies research methods. She is the principal investigator of the research project "Politics, Policy, and Populism in the New Media" and vice-chair of the working group on Populist Actors as Communicators in COST Action IS1308 "Populist Political Communication in Europe". Her work focuses mainly on political communication, comparative media studies, and Internet and politics. 